\title{
Ad Libitum Feeding of Either a Complete Ration Based on Sugarcane Bagasse or a Conventional Concentrates Mixture to Dairy Cows
}

\author{
Paul F. Randel

\section{INTRODUCTION}

Rakes $(5)^{2}$ has reviewed the North American literature concerning the feeding of complete rations composed of mixtures of fibers and concentrate ingredients to dairy cows. Most fiber sources used commonly in complete rations on the continent are scarce and expensive in Puerto Rico. Sugarcane bagasse, however, is plentiful and rather inexpensive.

In a preliminary experiment, a complete ration composed of 15-percent chicken litter bagasse and 85-percent concentrates, fed ad libitum, was readily consumed by dairy cows and supported higher milk production than a conventional limited concentrates ration (6). The experiment herein reported was conducted to compare a complete ration containing a greater proportion of bagasse vs. a feeding program of silage and a conventional concentrates mixture. Both feeding regimes were ad libitum.

\section{MATERIALS AND METHODS}

Eleven Holstein and two Brown Swiss cows, with at least one previous lactation, were entered in the experiment on the sixth day of their lactation. All lactations started between September 1966 and February 1967. During the 25 days that followed, the preliminary period, all cows were confined in a shaded, concrete-floor pen of approximately 45 by 45 feet. The cows were group-fed both a conventional concentrates mixture (table 1) and a poor quality sorghum (Sorghum vulgare) silage, both ad libitum. Wasted silage was used as bedding. The cows left the pen only to go the milking parlor at approximately 6 a.m. and 3 p.m. daily. In addition, the cows were given 2 pounds of the conventional concentrates mixture during each milking.

Upon completion of the preliminary period, each cow was assigned to one of two treatments of a double-reversal experiment: Treatment A consisted of continuing the feeding schedule used during the previous period; and treatment $B$, in which the cows were placed in partially paved

1 Animal Nutritionist, Agricultural Experiment Station, Mayagüez Campus, University of Puerto Rico, Lajas, P.R. The author acknowledges the assistance of Edgardo Prieto Rodriguez in analyzing milk samples, and of the Central Analytical Laboratory at Rio Piedras in analyzing feed samples taken during the course of this experiment.

2 Italic numbers in parentheses refer to Literature Cited, pp. 437-8. 
and shaded outdoor corral, measuring approximately 75 by 105 feet, where they were group-fed a complete ration ad libitum consisting of ground sugarcane bagasse mixed with concentrate ingredients (table 1 ). They were

TABLE 1.-Formulas of the concentrate mixtures and proximale chemical composition (in percent) of all.feeds used in the experiment

\begin{tabular}{|c|c|c|c|c|}
\hline \multirow{2}{*}{ Ingredient } & \multicolumn{4}{|c|}{ Formula } \\
\hline & \multicolumn{2}{|c|}{$\begin{array}{l}\text { Conventional concentrate } \\
\text { mixture }\end{array}$} & \multicolumn{2}{|c|}{ Complete ration } \\
\hline $\begin{array}{l}\text { Ground shelled corn } \\
\text { Soybean oil meal } \\
\text { Tunafish meal } \\
\text { Cane molasses } \\
\text { Ground bagasse } \\
\text { Bonemeal } \\
\text { Salt } \\
\text { Sodium bicarbonate } \\
\text { Vitamin supplement² }\end{array}$ & \multicolumn{2}{|l|}{$\begin{array}{l}65.0 \\
10.0 \\
10.0 \\
12.5 \\
\overline{1.0} \\
1.0 \\
.5 \\
-\end{array}$} & \multicolumn{2}{|r|}{$\begin{array}{r}40.20 \\
10.00 \\
5.00 \\
20.00 \\
22.50 \\
1.00 \\
.75 \\
.50 \\
.05\end{array}$} \\
\hline Total & \multicolumn{2}{|l|}{100.0} & \multicolumn{2}{|r|}{100.00} \\
\hline \multirow{2}{*}{ Item } & \multicolumn{4}{|c|}{ Chemical compositions } \\
\hline & $\begin{array}{l}\text { Conventional con- } \\
\text { centrate mixture }\end{array}$ & \multicolumn{2}{|c|}{$\begin{array}{c}\text { Complete } \\
\text { sation }\end{array}$} & Sorghum silage \\
\hline $\begin{array}{l}\text { Component } \\
\text { Dry matter } \\
\text { Crude protein } \\
\text { Ether extract } \\
\text { Crude fiber } \\
\text { Ash } \\
\text { Nitrogen-free extract }\end{array}$ & $\begin{aligned} 87.8 & \pm 1.04 \\
19.4 & \pm 0.8 \\
2.8 & \pm 0.7 \\
1.9 & \pm 0.2 \\
7.2 & \pm 0.3 \\
68.8 & \pm 0.7\end{aligned}$ & \multicolumn{2}{|c|}{$\begin{array}{r}88.2 \pm 0.5 \\
13.1 \pm 0.7 \\
1.9 \pm 0.2 \\
13.3 \pm 0.9 \\
6.3 \pm 0.3 \\
65.3 \pm 1.1\end{array}$} & $\begin{aligned} 25.4 & \pm 2.6 \\
5.6 & \pm 1.0 \\
1.2 & \pm 0.2 \\
35.4 & \pm 3.9 \\
10.6 & \pm 1.5 \\
47.2 & \pm 4.2\end{aligned}$ \\
\hline Number of samples analyzed & 7 & \multicolumn{2}{|c|}{10} & 4 \\
\hline
\end{tabular}

1 Ground to pass a 1/4-inch screen.

2 Generously supplied by Dawe's Laboratories, Inc., Chicago, Ill., and containing $3,000,000$ USP units of stabilized vitamin A, 200,000 IC units of vitamin D-3, and $10,000 \mathrm{IU}$ of vitamin $\mathrm{E}$ per pound.

s On a dry-matter basis for all components except dry matter.

1 The figures presented are means and standard deviations.

also given 2 pounds of the complete ration at each milking. The three periods of the double-reversal design were of 10 weeks duration each. The first 3 weeks of each period were an adjustment phase; the remaining 7 weeks a comparison phase. 
Twenty-four hour aliquot milk samples were collected from each cow at the end of the preliminary period, at the end of each adjustment phase, at the middle, and at the end of each comparison phase. The samples were analyzed for both fat and protein following the A.O.A.C. methods (1), and for solids-not-fat as described by Watson (10). Each cow was weighed in the morning, following a fast of at least 14 hours, at the end of the preliminary period and of each comparison phase. The weight of the milk produced at the milking immediately following the fast was subtracted to determine the net shrunk live-weight.

Eight of the 13 cows that began the experiment were assigned to the treatment sequence B-A-B, and five were assigned to the sequence A-B-A. Unfortunately, two cows of the former group were lost from the experiment, one due to lactational failure and the other to hypocalcemia provoked by an overnight fast prior to weighing (7). One cow of the latter group also was lost from the experiment due to an error in procedure; this cow was switched between treatments at the wrong time and the error was not discovered soon enough to be rectified. Because all three of these cows completed the first comparison phase, an attempt was made to extract something useful from their partial data. Thus, analyses of covariance were performed employing the data from all 13 cows during the first comparison phase as the dependent variable and the corresponding data from the preliminary period as the independent variable (9). Complete data were available from six cows following the treatment sequence B-A-B and from four cows following the A-B-A sequence. The data from these 10 cows were analyzed by statistical procedures for double-reversal experiments (2).

\section{RESULTS}

Upon changing from a moderate level of concentrates intake to ad libitum consumption on the sixth day of lactation, several cows suffered acute indigestion. This effect of abrupt high-level concentrates feeding is well known (3). The sick animals were drenched with saturated limewater and regained their appetites within 2 or 3 days. Due to this experience, it was decided that thenceforth, whenever a cow changed treatments, she would be kept in a stanchion for several hours daily and offered a gradually decreasing amount of silage before being allowed to eat concentrate feeds. Once adjusted to treatment $A$, the cows consumed the conventional concentrates mixture at high levels without ill effects. The average daily consumption of concentrates for 13 cows during the preliminary period was 33.3 pounds per head (table 2). Silage consumption was not very great, averaging only 29.5 pounds per cow daily during the same period. During the first comparison phase, the five cows on treatment A consumed 37.0 
pounds of conventional concentrates mixture and 30.5 pounds of silage per cow daily.

Some of the cows ate the complete ration reluctantly for the first few days. However, very high levels of consumption were reached eventually. The highest daily consumption recorded was 54.8 pounds per head. During the first comparison phase the eight cows on treatment $B$ averaged 48.0 pounds of complete ration consumed daily (table 2). Among the 10 cows which completed the experiment, feed consumption on treatment A was nearly constant during all three comparison phases. The average daily intake of concentrates varied only from 35.2 to 37.5 pounds, and that of silage from 29.4 to 30.6 pounds. By contrast, the cows ate progressively

TABLE 2.-Average daily feed consumption figures (in pounds)

\begin{tabular}{l|c|c|c}
\hline \multicolumn{1}{c|}{ Portion of the experiment } & $\begin{array}{c}\text { Conventional concen- } \\
\text { trate mixture }\end{array}$ & Sorgbum silage & Complete ration \\
\hline \multicolumn{3}{c}{ Including dala from 13 cows } \\
\hline Preliminary period & 33.3 & 29.5 & - \\
Comparison phase I & 37.0 & 30.5 & 48.0 \\
\hline \multicolumn{5}{|c|}{ Including dala from 10 cows } \\
\hline Comparison phase I & 36.5 & 30.6 & 48.5 \\
Comparison phase II & 37.5 & 30.5 & 46.3 \\
Comparison phase III & 35.2 & 29.4 & 40.9 \\
Total experiment1 & 36.6 & 30.2 & 45.1 \\
\hline
\end{tabular}

1 Averages over the whole experiment were calculated by weighting comparison phase II twice as much as each of comparison phases I and III.

less of the complete ration in each successive comparison phase; yet the average daily consumption was still above $\mathbf{4 0}$ pounds even in the third comparison phase.

During the preliminary period the cows of the two different treatmentsequence groups produced similar average amounts of milk and of milksolids constituents (table 3), and showed similar milk composition, except for a fairly appreciable difference in milk fat percentage (table 4). There were slight tendencies for production of milk and of milk-solids constituents to increase from the preliminary period to the first comparison phase among the cows switched to treatment $B$ and to decrease among the cows remaining on treatment $\mathrm{A}$. However, covariance analyses including data from 13 cows showed no significant differences between treatments either in milk production or in production or percentage of the various milk-solids constituents during the first comparison phase. 
A progressive decline in production of milk and of milk-solids constituents was noted in the cows of both treatment-sequences in successive comparison phases (table 3 ). The six cows on the B-A-B sequence were more productive than the four cows on the opposite sequence. The differences between treatments in production of milk and of milk-solids constituents during the double-reversal experiment were not significant. However, the difference

TABLE 3.-Average daily productions of milk and milk-solids constituents (in pounds)

\begin{tabular}{l|c|c|c|c|c}
\hline Item & Milk & Fat & $\begin{array}{c}\text { Solids-not- } \\
\text { fat }\end{array}$ & Total solids & Protein \\
\hline & \multicolumn{5}{|c}{ Including data from 13 covs } \\
\hline $\begin{array}{l}\text { Preliminary period } \\
\text { Treatment A }\end{array}$ & 56.5 & 1.6 & 5.0 & 6.6 & 1.7 \\
Treatment B1 & 54.9 & 1.7 & 4.8 & 6.5 & 1.7 \\
Comparison phase I & & & & & \\
Treatment A & 53.1 & 1.5 & 4.8 & 6.3 & 1.8 \\
Treatment B & 56.9 & 1.8 & 5.2 & 7.0 & 2.0 \\
\hline
\end{tabular}

\begin{tabular}{|c|c|c|c|c|c|}
\hline & & Incl & ala fron & & \\
\hline Comparison phase I & & & & & \\
\hline Treatment A & 49.9 & 1.4 & 4.6 & 6.0 & 1.7 \\
\hline Treatment B & 60.1 & 1.9 & 5.5 & 7.3 & 2.1 \\
\hline Comparison phase II & & & & & \\
\hline Treatment A & 52.0 & 1.5 & 4.7 & 6.2 & 1.9 \\
\hline Treatment B & 42.9 & 1.4 & 3.9 & 5.3 & 1.5 \\
\hline Comparison phase III & & & & & \\
\hline Treatment A & 39.0 & 1.3 & 3.5 & 4.8 & 1.3 \\
\hline Treatment B & 42.5 & 1.5 & 3.8 & 5.3 & 1.4 \\
\hline Total experiment ${ }^{2}$ & & & & & \\
\hline Treatment A & 48.6 & 1.4 & 4.4 & 5.8 & 1.7 \\
\hline Treatment B & 47.4 & 1.5 & 4.3 & 5.8 & 1.6 \\
\hline
\end{tabular}

1 Cows destined to receive the treatment indicated in the first experimental period.

2 See footnote to table 2.

for milk fat percentage was highly significant $(P<.01)$ and that for milk total solids percentage was significant $(P<.05)$ in favor of treatment $B$ (table 4). The abnormally low milk fat percentage of 2.85 for treatment A can be attributed to the excessively wide concentrates:forage ratio consumed (4). The 0.5 percent of sodium bicarbonate in the conventional concentrates mixture was insufficient to counteract this effect. Neither milk solids-not-fat nor protein contents were significantly affected by the treatments. 
Both of the treatments promoted liveweight gains throughout the double-reversal experiment and no significant difference between treatments was found (table 5). The cows on treatment-sequence A-B-A gained more liveweight in each period than did those on sequence B-A-B. Apparently the former cows possessed lesser lactogenic capacity and tended to divert more of the nutrients they consumed into body fat rather than milk production.

Table 4.-Average percentages of milk-solids constituents

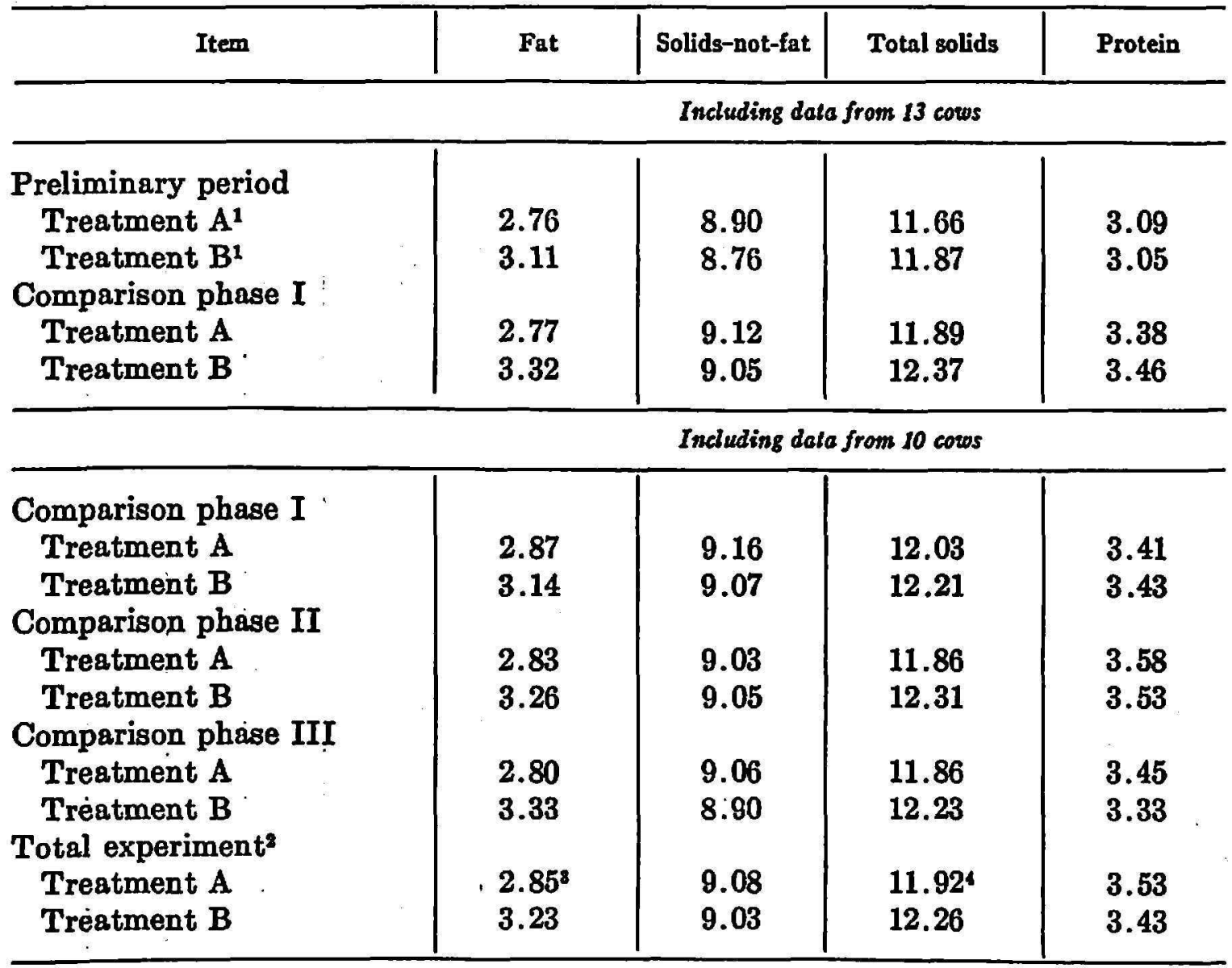

1,2 See footnotes to table 3.

- Difference between treatments highly significant $(P<.01)$.

- Difference between treatments significant $(P<.05)$.

Aside from the aforementioned indigestion, the only other health problem encountered was mastitis. Two of the cows suffered three attacks of mastitis each, and another animal was afflicted twice. Four of the eight cases of mastitis occurred in each treatment. In the six occasions when mammary inflammation caused a noticeable decline in milk production, normal production for the affected interval was estimated from the average production during the 5 preceding and the 5 following days. Such estimated production was employed for 50 cow-days altogether. 


\section{DISCUSSION}

Treatment $A$ was used as a standard against which the complete ration could be compared, in spite of the fact that ad libitum concentrates feeding is not an economical practice in Puerto Rico due to the expense of importing feed grains. However, high-quality forages were not available for this experiment; therefore, liberal feeding of concentrates was the only means of assuring a more rigorous standard than that employed in the preliminary experiment at this substation, in which poor-quality forages constituted a large part of the ration (6). Although milk fat percentage was depressed, the animals on treatment $A$ remained apparently in normal health and presumably produced milk at nearly maximum capacity. The complete ration was statistically equal to the standard in promoting milk production, thus it too must have enabled the cows to achieve nearly their full productive potential. With respect to milk composition, the complete ration

TABLE 5.-Average daily liveweight gains (in pounds) of the 10 cows which completed the experiment

\begin{tabular}{c|c|c|c|c}
\hline \multirow{2}{*}{ Treatment . } & \multicolumn{4}{|c}{ Experimental period } \\
\cline { 2 - 5 } & I & II & II & Total \\
\hline A & 1.30 & 1.06 & 1.28 & 1.15 \\
B & 1.06 & 1.23 & 0.67 & 1.01 \\
\hline
\end{tabular}

1 See footnote to table 2.

was significantly superior to the standard in maintaining normal percentages of fat and total solids.

The principal changes made in the formula of the complete ration for the present experiment, relative to that of the previous experiment (6), were the inclusion of 7.5 percent more bagasse and 5.0 percent more molasses, with corresponding reductions in soybean meal and shelled corn. The level of milk production on the complete rations averaged exactly the same in this and in the previous experiment ( 47.4 pounds daily), and the milk composition was similar. The average daily consumption of the complete ration was slightly greater in the present experiment (45.1 vs. 43.6 pounds), as was the average daily liveweight gain (1.01 vs. 0.78 pounds). Thus it was possible to reduce the proportion of imported concentrates and increase that of bagasse and molasses in the complete ration and still support the same level of production.

The complete ration of treatment B was also tested at the Gurabo Substation in four groups of three Holstein cows each over a continuous 
205-day comparison period (8). Less favorable productive responses were obtained in the latter case, which probably was attributable to cows of lower productive capacity and possibly to the adverse effect of uncomfortable pens.

\section{SUMMARY}

Two feeding regimes were compared using 13 lactating cows (11 Holstein-Fresian and two Brown Swiss) confined in corrals. The rations consisted of a conventional concentrates mixture and sorghum silage in treatment $A$, and of 22.5 percent sugarcane bagasse mixed with 20.0 percent molasses and 57.5 percent other concentrates (complete ration) in treatment B. The experimental design was a double-reversal with 10 -week periods, each divided into a 3-week adjustment and a 7-week comparison phase, preceded by a 25-day preliminary period.

During the 7 weeks of the comparison phase of the first of the three experimental periods, five cows on treatment $A$ averaged 37.0 pounds of concentrates and 30.5 pounds of silage consumption daily, while eight cows on treatment $B$ consumed an average of 48.0 pounds of the complete ration. Average daily milk production with these respective rations during the comparison phase in question was 53.1 and 56.9 pounds. No significant differences between treatments were found. Over the three experimental periods of the double-reversal, daily intakes averaged 36.6 pounds of conventional concentrates mixture, 30.2 pounds of silage, and 45.1 pounds of complete ration. On treatments $A$ and $B$, daily milk production averaged 48.6 and 47.4 pounds; milk fat percentage, 2.85 and 3.23 ; milk solids-notfat percentage, 9.08 and 9.03 ; milk total solids percentage, 11.92 and 12.26; milk protein percentage, 3.53 and 3.43; and daily liveweight gain, 1.15 and 1.01 pounds, respectively. The difference between treatment means was significant for milk fat $(P<.01)$ and milk total solids $(P<.05)$ percentages.

Since the complete ration resulted in productive performance comparable to that obtained with ad libitum consumption of conventional concentrates, it is concluded that the former is capable of sustaining milk production at nearly maximum capacity. Milk production on treatment $B$ was also equal to that obtained in a previous experiment with a complete ration containing 7.5 percent less bagasse and 5.0 percent less molasses, and correspondingly higher proportions of soybean meal and shelled corn.

\section{RESUMEN}

Se compararon 2 regímenes alimenticios con 13 vacas lactantes (11 Holstein-Fresian y 2 Suiza Parda) confinadas en corrales. La ración en el tratamienio A fue una mezcla corriente de ingredientes concentrados y ensilaje de millo; la ración en el tratamiento B fue una mezcla de 22.5 por 
ciento de bagazo de caña de azúcar, 20.0 por ciento de miel de caña y 57.5 por ciento de otros ingredientes concentrados para hacer una "ración completa". El diseño experimental fue una reversión doble con periodos de 10 semanas, consistente cada uno de 3 semanas para adaptarse a régimen y 7 para la fase comparativa, ambos precedidos por un periodo preliminar de 25 días.

Durante las 7 semanas de la fase comparativa del primero de los 3 periodos de experimentación, las cinco vacas del tratamiento A consumieron diariamente un promedio de 37.0 libras de alimento concentrado corriente y 30.5 libras de ensilaje, mientras que las ocho vacas del tratamiento $B$ consumieron 48.0 libras de la ración completa. Con ambas raciones la producción diaria de leche promedió durante la fase aludida 53.1 y 56.9 libras, respectivamente. No se encontró diferencia significativa alguna entre los tratamientos. Durante los 3 periodos de experimentación de la reversión doble, el consumo diario promedió 36.6 libras de alimento concentrado corriente, 30.2 libras de ensilaje y 45.1 libras de la ración completa. La producción diaria de leche con los tratamientos A y B promedió 48.6 y 47.4 libras, con un porcentaje de grasa de 2.85 y 3.23 ; un porcentaje de sólidos no grasos de 9.08 y 9.03; un porcentaje de sólidos totales de 11.92 y 12.26; un porcentaje de proteina de 3.53 y 3.43 ; y un aumento diario en peso vivo de 1.15 y 1.01 libras, respectivamente. Las diferencias entre los tratamientos fueron significativas, con respecto al porcentaje de grasa $(\mathrm{P}<.01)$ y el porcentaje de sólidos totales $(\mathrm{P}<.05)$.

Se concluye que la ración completa podría sostener la producción de leche a casi la capacidad máxima de las vacas, ya que con ella se logró una producción comparable a la que se obtuvo al suministrarse alimento concentrado corriente ad libitum. Además, la producción obtenida con el tratamiento $B$ fue igual a la que se obtuvo en un experimento previo con otra ración completa, que contenía un 7.5 por ciento menos de bagazo y un 5.0 por ciento menos de miel, y mayores proporciones de harina de soja y de maíz en grano.

\section{LITERATURE CITED}

1. A.O.A.C., Official Methods of Analysis, 9th ed. Washington, D.C., 1960.

2. Brandt, A. E., Test of significance in reversal or switchback trials, Iowa Agr. Exp. Sta. Res Bull. 234, 1938.

3. Hungate, R. E., The Rumen and Its Microbes, Academic Press, New York, pp. 454-7, 1966.

4. Laben, R. C., Factors responsible for variation in milk composition, J. Dairy Sci. 46: 1,293-301, 1863.

5. Rakes, A. H., Dairy cattle feeding. Complete rations for dairy cattle, J. Dairy Sci. 68: 870-5, 1969.

6. Randel, P. F., Feeding lactating dairy cows concentrates and sugarcane bagasse as compared with a conventional ration, J. Agr. Univ. P.R. 60: 255-69, 1966. 
7. —, Transient effects on milk production of a fourteen-hour overnight shrink before liveweight determinations of dairy cows, J. Dairy Sci. 51: 624-5, 1968.

8. Randel, P. F., Soldevila, M., and Salas, B., A complete ration composed of concentrates and sugarcane bagasse versus a conventional ration of Pangolagrass and supplemental concentrates for milk production, J.Agr.Univ.P.R. 68: 167-76, 1969.

9. Snedecor, G. W., Statistical Methods, 5th ed., Iowa State College Press, Ames, Ia., pp. 394-400, 1956.

10. Watson, P. D., Determinations of the solids in milk by a lactometric method at $102^{\circ}$ F., J. Dairy Sci. 40: 394-402, 1957. 